\title{
Changes in Multinational Industrial Enterprises through the Adoption of Innovation: Case of E-Business in Brazilian and Foreign Capital Companies
}

\author{
Silvia Novaes Zilber, Marcelo Scorsato de Rosa
}

Graduate Program in Business, Uninove University, Sao Paulo, Brazil.

Email: silviazilber@gmail.com

Received June $11^{\text {th }}$, 2013; revised July $10^{\text {th }}, 2013$; accepted August $5^{\text {th }}, 2013$

Copyright (c) 2013 Silvia Novaes Zilber, Marcelo Scorsato de Rosa. This is an open access article distributed under the Creative Commons Attribution License, which permits unrestricted use, distribution, and reproduction in any medium, provided the original work is properly cited.

\begin{abstract}
The objective of this study was to understand the changes that took place in large multinational industries acting in the physical world that, by adopting e-business, started acting in the virtual world, as well as the needs that led to this adoption. Method: multi-case study with two companies, a national industry ("A") and a subsidiary of a developed country ("B") in Brazil. Results: In terms of motivation, both companies mentioned an increase in revenue, but "B" highlighted its alignment with global strategy, focused on innovation and e-business, as a "showcase" of the company's innovative side. Logistical transformations: "A" hired a logistics operator; "B" developed internally adapted logistics, taking advantage of knowledge from its headquarters.
\end{abstract}

Keywords: E-Business Adoption; Multinational Industries; Innovation; Logistics; Organizational Structure

\section{Introduction}

Most large industries established in Brazil have their roots in the "physical world" and did not have activities in the "virtual world" at the time when the Internet came to be. However, with the advent of the Internet as a business tool, many companies began to understand that this tool could be a way to further their business, leading companies to adapt their operations to the virtual world and expand their commercial frontiers.

Turban et al. (2006) [1] define "e-business" as activities that use the Internet to facilitate the trade (purchase and/or sale) of goods, the provision of services to the consumer, collaboration with commercial partners and the performance of transactions within an organization.

One of the great innovations brought about by the Internet was disintermediation. Large industries historically did not directly connect to their end clients and therefore required that middle-men could now make such a connection. Mehta \& Shah (2011) [2] identify several reasons to incorporate e-business as a new distribution channel for companies, with particular emphasis on the potential for geographic expansion and greater exposure in current markets.
E-business has been growing in recent years. Data from the Brazilian Institute of Public Opinion and Statistics (Instituto Brasileiro de Opinião Pública e Estatística) - IBOPE (2012) [3] show that the number of Brazilians that access the Internet has reached 79.9 million in the fourth quarter of 2011, an increase of $8 \%$ relative to the same period in 2010. The website e-commerce.org (2011) [4] states that, in Brazil, online sales clearly tend to increase and that since 2008, the billing of e-business has grown $30 \%$ yearly and is expected to maintain this rate over the next three years. The website Internet World Statistics (2011) [5] reports that Brazil currently has 76 million Internet users, a number that has grown 900\% since 2000 .

Tigre \& Dederick (2003) [6] state that e-business has become an instrument that is increasingly used by traditional organizations as a means to complement their business. Of the various types of transactions that occur in e-business, perhaps one of the most well-known is business-to-consumer (B2C), i.e., business between companies and end consumers, a practice also known as electronic commerce or $e$-commerce for short.

By adopting e-business or, more specifically, e-com- 
merce, industries establish an innovation process regarding the implementation of new ideas in a given context and assume collective interactions (Sternberg; Pretz; Kaufman, 2003) [7]. Porter (2001) [8] states that the issue is not whether companies should use the Internet to do business but rather how best to use it if the company is to remain competitive. Regarding achieving this aim, the key challenge is the possession or implementation of an organizational structure capable of handling this demand.

Many companies in the real world are trying to change their structures to support a virtual business model, as stated by Kalakota \& Robinson (2004) [9]. Although there has been considerable study on the subject of retail companies operating in the electronic world, little has been written about industries using B2C as a means to directly contact their end clients. This new operation impacts various segments of the company. Once disintermediation takes place, tasks that were previously delegated to an intermediary, such as delivering products to the end consumer, must now be addressed by the Industry itself, which did not have to do this before adopting e-business. When implementing B2C models, industries also need to adapt with respect to merchandise volume, because traditionally, industries sell to distributors and wholesalers, who tend to require large production volumes. However, the logistics of an e-business model generally involves small volumes; this transition is a very complex operation for industries that did not previously operate in the virtual world.

In this context, the goal of this study was to understand the changes caused by the adoption of e-business or, more specifically, e-commerce (a B2C relationship), in large multinational industries that acted in the physical world and started acting in the virtual world, as well as the needs that led to this adoption. Of the changes that were investigated, the focus was first on those taking place in the organizational structure of the companies under study, given the relevant role of a company's organization in taking advantage of the opportunities of e-business. Secondly, attention was also given to the transformations that took place in these companies' logistics because, although the adoption of e-business is associated with significant advances in commercial transactions, according to Barlow et al. (2004) [10], the same does not happen with logistic flow, subjecting B2C consumers to new logistic bottlenecks in addition to those that existed in the normal distribution process. To Fuchs \& Fleury (2003) [11], fractionating delivery to the B2C client is recognized as one of the greatest challenges to companies, due to both the geographic comprehensiveness and the obligation to deliver the product directly to the consumers' house.
This study had the following goals:

- Identify the needs that led organizations to adopt e-business;

- Verify the main changes that took place in the logistic processes and the organizational structures of the industries under study due to the adoption of e-business, specifically B2C;

- Identify the benefits and difficulties stemming from the adoption of e-business.

To achieve these goals, two multinational industrial enterprises were studied; one with roots in a developed foreign country that was active in Brazil as subsidiary and another of national origin that was founded in Brazil. The companies chosen, aside from being high-profile multinationals, have one particularly relevant difference. The national company is a headquarters, while the foreign multinational is a subsidiary. These companies were chosen to determine the differences in the adoption of innovation due to either a headquarters or a subsidiary. For the headquarters, e-business is something completely new, while for the subsidiary, e-businessis a roll out because its headquarters has already implemented this process in other countries and therefore has knowledge and experience obtained outside of Brazil.

According to Stal \& Campanario (2011) [12], the academic interest of national capital in Brazilian multinational companies is relatively new, not older than two decades. There are dozens of studies focused on companies of Southeastern Asia but very few about Latin American companies, further justifying the study of adopting such a Brazilian multinational innovation.

The following section is a review of the literature used to elaborate the questionnaire and analyze the results obtained. Next, the investigation methods applied in the study are presented, followed by the results and analysis and closing remarks.

\section{Literature Review}

The theoretical foundation for the present study is presented here. First, we describe the concept of e-business, understood as an innovation, and how this innovation is related to the concepts of organizational structure and logistics, followed by the concepts of Brazilian and foreign multinationals.

Turban et al. (2006) [1] observe that the origin of e-business dates back to the 1970s, starting with data transfer, more commonly known as electronic data interchange (EDI). These authors claim that new applications followed the initial ones, from stock negotiation to the purchase of flight tickets. Mishra (2010) [13], states that e-business is becoming one of the best ways to do business. However, companies in emerging countries still struggle to develop e-business in a sustainable way and 
often need to modify their internal structures to promote this innovation. E-business is a fusion of commercial processes, enterprise applications and organizational structure required to create or enhance the traditional model of the company (Kalakota; Robinson, 2004 [9]). In Brazil, e-business initially spread through financial transactions and inside company networks that supported this functionality (Tigre; Dedrick, 2003 [6]). With the widespread use of the Internet, e-business extended its reach to end users, raising companies' revenues along with the number of consumers using this channel to acquire products and services.

Because the adoption of e-business is understood as an innovation for the adopting industry in the present study, it behooves us to define what is meant by innovation and its adoption. Rogers (1995) [14] defines innovation as an idea or object that is identified by the individual as something new. The development process of innovation consists of all decisions and activities, as well as their respective impact in the event of a necessity or problem, during there search, development and commercialization of an innovation. In the Oslo Manual (OCDE, 2005) [15], innovation is a vision based on knowledge and focused on interactive processes through which knowledge is created and exchanged within and between companies. Tidd, Bessant \& Pavitt (2008) [16] define innovation as a change process driven by the ability to establish relationships, detect opportunities and take advantage of them. These authors divide it into four distinct categories: product, process, position and paradigm innovation. For the present study, one may consider the adoption of e-business as a process innovation.

For large industries that operated only in the real world, adopting e-business is an innovation. However, there are obstacles, as noted by Johnson (2010) [17], including risk perception, lack of knowledge, trust and organizational availability.

In multinational companies, innovations can be transferred between subsidiary companies, from the headquarters to subsidiaries and vice-versa. Thus, multinationals develop three types of organizational competence capable of contributing to the diffusion of innovation, according to Dunning (1993) [18], as follows: local competences, non-local competences and specific competences. Competences are important for the diffusion of innovation among subsidiaries because they enable companies to create or adapt innovation to their local environment. Subsidiaries that adapt innovations transferred from their head quarters are creating local innovation; those that develop innovation but have difficulty transferring it back to the headquarters, or vice-versa, create specific innovations; and finally, subsidiaries that adapt or develop innovations that are later adopted by others are creating non-local innovations. According to Oliveira Jr., Boehe \& Borini (2009) [19], the greater the autonomy of a subsidiary, the greater its decision power and the capacity to develop innovation initiatives are. However, excessive autonomy may hinder the exploitation of internal initiatives by the multinational corporation and may lead to innovation decisions that target diverging objectives, causing a rupture in corporate strategy.

Foreign multinationals have well-known brands, innovation processes tested in other countries, sophisticated technologies, efficient management systems, financial resources that do not always have their origin in the host country because they seek lower interest rates and efficient networks of suppliers, distributors and logistics (Khanna; Palepu, 2006 [20]). According to Khanna \& Palepu (2006) [20], multinational companies that are developed in emerging nations have institutional deficiencies consisting of the lack of efficient innovation systems and regulation, as well as volatile political and economic environments and consumers who, although demanding, are sensitive to prices; an efficient innovation management might mitigate such difficulties. In the case of a subsidiary acting in an emerging nation, knowledge may be transferred from the headquarters in a developed country; knowledge is of particularly high value, considering that foreign markets grant access to new ideas and stimuli that can be applied in emerging nations where the multinational operates (Oliveira Jr., 2007 [21]). The comparison between national and foreign multinational companies in the domestic markets of emerging nations shows that the former develop competence, skills and trust that allow it to compete with foreign companies (Stal; Campanario, 2011 [12]), and, as a consequence, it becomes more competitive in the market in which it operates. Therefore, the study of these multinationals and their innovations, which can lead to competitive advantages, is an important part of the study presented in this article.

Regarding the transformations that may occur in the organizational structure of companies that adopt innovation, in this case, e-business, Vasconcellos \& Hemsley (2003) [22] claim that the speed of change and the increase in the complexity of the environment in the last few decades made it necessary to develop structures to effectively respond to these changes. For a long time, a certain set of structural patterns were employed by many kinds of organizations. These structures are defined as the result of a process in which authority is distributed to activities in all levels, from the lowest to the highest. Responsibilities are specified, and a communication system is designed to allow people inserted in this structure to perform tasks and exert the authority they have to achieve the company's objectives (Vasconcellos; Hem- 
sley, 2003 [22]). In terms of organizational structure, Costa et al. (2010) [23] state that structures without many hierarchical levels that are oriented towards multifunctional teams are better able to adapt to mutating environments that seek innovation.

Regarding the impact of the adoption of e-business on the logistics of the adopting companies, Bornia et al. (2006) [24] state that, as a result of this new age of economics where each Internet access may result in a new purchase, logistics serve e-business as a value-aggregateing activity, and companies exploiting this strategy may obtain competitive edges that will allow their survival and grant financial return. Following Coelho \& Cristo (2007) [25], B2C e-business requires differentiated logistics with particular characteristics that are not traditionally available, such as the integration between information on the availability of a given product on the site (front end) and the actual availability of the said product in stock (back office). In traditional logistics, a material good is thought of as a well-established physical position; in virtual logistics, however, what matters is that the product be available when necessary. According to Alves et al. (2005) [26], while traditional logistic systems are developed to serve commerce between companies with orders of large volume, in which most deliveries are made to distribution centers or stores, the logistics of virtual commerce are characterized by a large number of small orders that are geographically spread out and fragmentally delivered, resulting in low demographic density and high delivery cost (ALVES et al., 2005 [26]). B2C e-business requires differentiated logistics with particular characteristics that are not provided by traditional logistics. True, its logistics do present, in a sense, the same concepts as the traditional ones, but they are adjusted to the specific characteristics of an e-business environment (BORNIA et al., 2006 [24]). Tools that are very similar to those used in traditional logistics are employed here; however, they must be adapted according to the particular traits of the process. The adaptation can be considered an innovation for companies that were not founded in a virtual environment but wish to enter this model to service previously unreachable clients.

\section{Investigation Method}

This study was undertaken with an exploratory aim, is of a qualitative nature, and employed a multiple case study method in which the companies were studied by means of interviews using semi-structured questionnaires, documents made available by the companies and analysis of their websites, thus allowing data triangulation. Vieira (2004) [27] states that qualitative study has been used in some specific fields of study in applied social sciences, and it can be defined as having its main foundation in the analysis of qualitative data, i.e., it is characterized by not making use of statistical instruments of data analysis. According to Yin (2003) [28], qualitative methods allow the researcher to gain an overview of events within the context of real life, and their use is appropriate in studies that aim to understand complex social phenomena. Given that this study tries to understand, first, the transformations caused by the adoption of e-business, and more specifically, e-commerce (B2C relationship), by large multinational industries that were originally active in the physical world and then started acting in the virtual world, and secondly, the motivations for this adoption, exploratory research of a qualitative nature seemed appropriate. The method chosen for this exploratory investigation was the multiple case study, which allowed for acomparison between the companies participating in the study in terms of how they innovated, their different adaptation processes and the difficulties encountered while adopting innovation.

The companies chosen for the study were selected because they are multinational, one from an emerging nation (Brazil) and one from a developed country, and also because are both large businesses that sell directly to the consumer through e-business (B2C). These criteria greatly constrained the scope of this study because there are few industries in Brazil that sell directly to the end client through the Internet. The comparison between companies of different origins is pertinent because the aim is to investigate whether the branch office acting in Brazil can benefit from the knowledge obtained from the experiences of the headquarters. The companies that were interviewed do not belong to the same segment; however, both are characterized by the production of consumer goods and by having their own websites where they sell directly to the end consumer. This choice was made because two multinationals in the same field but of different capital, i.e., one national and one foreign, both selling their product directly through the Internet, could not be found. Data were gathered through semi-structured interviews and via examination of documents provided by the company, newspaper and magazine articles, the companies' websites and academic articles about the companies. Regarding the semi-structured interviews, nine employees of company "A" and eight of company "B" were interviewed; these employees held positions such as Wholesale Director, Marketing Manager, E-business Manager, New Media Communications Manager, Distribution Manager, Transport Manager, Distribution Center Operator, Supply Chain Manager and New Business Manager, among others. Each interview took approximately one hour, and the subjects were persons designated by the companies themselves as those best quailfied to help reach the objectives of the present study. 
Complementary data were obtained later through telephone communication and also by e-mail exchange to clarify some details. The analysis of the data consisted ofexamining, categorizing, and classifying or, alternatively, recombining the qualitative evidence to meet the end goal of the study. No statistical procedures were used to analyze the data because the whole study was grounded on a qualitative approach (Godoy, 2006) [29]. Because this study's investigation is of exploratory character, there was no intention to establish variable correlation.

\section{Results and Analyses}

The obtained results are presented in this section; both companies under study are introduced, and the evidence that was analyzed to reach the proposed objectives is described.

\subsection{Implementation of E-Business in Company "A"}

The national capital company, referred to in this study as company " $\mathrm{A}$ ", is the largest shoe company in Latin America in terms of units produced, with $\mathrm{R} \$ 3$ billion in revenue in 2011, of which $\mathrm{R} \$ 2.5$ billion was from the domestic market. It holds $16 \%$ of the national shoe market and $55 \%$ of the rubber sandal market. It has 12,000 employees in Brazil and approximately 5000 abroad. Because the company was structured to sell large volumes to wholesalers, department stores or retail outlets, it did not have the knowledge of how to sell directly to the end consumer through e-business. "[...] The company had never before sold directly to the end consumer, and that was a change in our processes [...]", stated the marketing manager. Technical areas, such as Information Technology, had to hire consultants to develop the website, and at a later stage, specialized personnel were hired to manage the e-business component. The idea of adopting the e-business system sprung from the company itself and was fully developed in Brazil. The development of the Brazilian website served as a reference for the development of the online store for the US, Europe and some e-business initiatives in Southern Asia. The company has branches outside of Brazil; however, there was no knowledge transfer from these other units to Brazil. Instead, the Brazilian unit was the head quarters for the institutional development of e-business in its subsidiaries. In the interview, this fact is made evident by the e-business manager: "[...] we worked together with other companies because e-business is a completely new business that normally nobody in an industry fully masters and often, also, in physical retail, it is business-specific".

The project to develop e-business in company " $\mathrm{A}$ " started in a planned manner in 2007 and was consolidated in 2009, when the company put two brands of its portfolio at the end consumer's disposal. The development of e-business as a new channel for the consumer was not a simple task because of the size of the company, which had a large number of departments and personnel involved, in addition to the lack of specific training in the company to adopt this innovation at the time. Additionally, the development of e-business studied here was its second experience in selling products directly to the consumer. The first one occurred in 2005, was not successful and was abandoned in 2006. The adoption of e-business was attempted again in 2007. The interviews and accounts obtained in the present work refer to the second attempt by company "A" to adopt this type of business in 2007. The development took place in Brazil, but the internal knowledge necessary to promote the development of e-business was not available because this was a new activity for the company; therefore, technical training was sought by hiring specialized companies. Technical areas such as Information Technology hired consultants to develop the website, and at a later stage, specialized personnel were hired to manage the e-business.

The Brazilian headquarters did not interfere in the operational structure (warehousing and distribution) of the e-business in other countries. Therefore, subsidiaries had autonomy to hire locals for these services. The guidelines from the head quarters were focused on visual alignment, product organization and brand appeal (pictures of new products, colors and the company logo), in conformity with the Brazilian website, to guarantee brand preservation.

In company " $A$ ", the departments involved in this adoption understood that the objectives of this company behave differently, and further, there was no alignment between the objective of adopting e-business and the company's strategic objectives. However, during the interview process, it was concluded that the true motivation had been to increase sales. The process to develop e-business involved, initially, sales and marketing executives and, later, information technology executives. The involvement of logistics in the project's conception and implementation phase was not so markedly present as that of IT, as revealed by the following statements from the transport and distribution managers: "[...] a superficial involvement of logistics"; "[...] we know of the importance, but there was no greater involvement of logistics due to lack of appropriate knowledge and acknowledgement of the project's importance".

In the organizational structure, the e-business area was allocated to the Retail Board, which is responsible for the management of franchises and company stores. This 
board made their brands available for consumers to purchase through the Internet because this was a new area, and the company itself was not certain which board would be responsible for the management of e-business. One interviewee from retail said that a more appropriate place for e-business within the company was missing, i.e., company "A" did not have a specifically prepared area for this type of business and thus made use of the existing structures. There was no consensus regarding the necessity of conceiving an e-business project. Interviewees from sales and marketing admitted that the development had its origins in their areas: "[...] everything started in sales and marketing [...]" or "[...] they [sales and marketing] had the idea of organizing the products and making them available through the Internet [...]". Thus, it is apparent that the true motivations underlying adopting innovation were confounded, and there is no certainty as to what motivated this adoption.

The information gathered from interviewees from company "A" diverges on the necessity of adopting ebusiness. Data obtained in this study show that the company acted "in an amateur fashion and without a clear objective" that would justify the development and implementation of e-business, as reported by some e-business, company stores and sales managers. Some of the e-business objectives, as stated in these interviews, are as follows:

[...] "a differentiated status for the product, with a sophisticated flair”.

[...] "the opportunity forbrands in a field that grows, say, around two digits every year".

[...] "the goal is to make a mix of products available to the consumer thatis hard to find in the common store".

[...] "to make it easier to purchase, and provide a place where people can research information about the products".

In its second attempt to implement e-business in 2007, the organizational structure of the logistics of company "A" was called "Distribution" and was placed under the Supply Chain Board. Along with Logistics, the field of Planning was subordinate to this Board. The company justified placing logistics (i.e., distribution) under the same management because both pertain to the same chain of operations. In 2009, the cost to process orders from e-business was lower than that of traditional orders, even though the shipping cost was higher. The logistic flow to process an order proved to be advantageous when compared to the costs of maintaining a physical store, which has additional costs, such as employees, rent, taxes, water, electric power and building maintenance, etc.

Although they do not have physical contact with the product, consumers utilizing the e-business model have greater variety at their disposal, and in general, products cost less. Logistics, despite their importance and role as a strategic area for the success of activities related to this channel, had only superficial involvement in the process because the company opted to subcontract the logistic activities relevant to e-business, hiring a logistics operator to perform the warehousing, distribution and shipment of orders. The reason given for this subcontracting acknowledged that logistic operations for e-business are completely different from what the company already had in terms of shipment size. This was confirmed by means of an interview fragment stating "[...] the logistic process is completely different from that of a normal store or of a company's shipment's and the operator we hired had the required knowledge". The interviewees in the fields of Marketing and Logistics stated that clients started receiving their orders faster, and in addition, they emphasized that the service provided by the subcontracted operator is one of the best in the country in terms both of punctuality and product quality, i.e., the condition of the merchandise at the moment of delivery.

\subsection{Adoption of E-Business in Company " $B$ "}

Foreign capital company "B", founded in 1919 in Sweden, is a current global leader in electrical household appliances, selling over 55 million units per year in over 150 countries. The company focuses on product innovation based on extensive opinion polling to determine the real needs of consumers.

Oriented towards product and process innovation, it adopted B2C in 2004 without the intent to significantly increase revenue; instead, the company aimed to implement an innovation in Brazil that was already common practice in other countries, such as Italy. Thus, the main objective of adopting e-business was the alignment of the branch office's objectives with the company's global strategy, so that all countries shared the same processes and procedures, giving the headquarters greater control over its global operations. However, at the end of the implementation, they also gained commercial insight into e-business, similar to company "A". In the last three years, the process was considered to be consolidated by company "B" after a period of transformations in IT (Information Technology) and Logistics, areas considered to be essential to and responsible for the high performance demanded by consumers that favor the e-business channel to acquire their products.

Company "B" sees the adoption of innovation as something of extreme importance, reflected in are mark by the distribution center's operator: "[...] innovation is 'in the blood' of the company [...]". It is part of the company's mission to provide innovative products beyond consumers' expectations. However, even if the search for innovation is part of the company's mission, the Brazil- 
ian branch resisted the adoption of e-business (understood as innovation) because, at first, this was not an opportunity to increase sales but rather a model "suggested" by the headquarters to promote a global alignment with the operations in other countries.

Regarding organizational structure, the Brazilian branch of company "B" consists of five boards. Supply Chain and Sales are responsible for Logistics and E-Business. The Projects area, physically located in Curitiba (PR), is subordinate to the Supply Chain Board; this area is responsible for the development of new processes or procedures that originate from the headquarters or are idealized in the subsidiary itself. Company "B" planned to adopt e-business, and the Project Coordination area, responsible for the development and implementation of innovations originating from the headquarters, coordinated the whole process. After implementation, the professionals who were part of this coordination area were no longer part of the e-business staff and returned to the project area to work on development demands. As stated by the projects and new business manager: "[...] the company adopted this condition and invested because there is a culture of structured innovation, and it does not consider chance [...]”.

Interviewees stated that there was no change in the final design for e-business implementation as proposed by the Brazilian branch because the headquarters approved of and trusted the professionals who were responsible for the execution. These professionals consisted of a multidisciplinary team from the project and e-business areas. Company "B" thus implemented this electronic sales channel with a local team without having to hire third parties or consultants but instead involved all areas, such as logistics, finance and information technology, preserving the local traits of the country. Company " $\mathrm{B}$ " attributes a good deal of the success in this implementation to the support given by HR to the people who were involved in and affected by the innovation and the use of e-business.

The company's Logistics achieved national coverage, with a strong concentration in the Southeast. This is to be expected given that the main clients, large retailers, are concentrated in this region. With six companies shipping their products, company "B" acquired relevant experience in delivering large volumes concentrated in a few clients, and until the start of the e-business project, it did not ship directly to the end consumer. The internal operational structure is the same for the logistics of e-business as for the traditional one, i.e., the logistics personnel of company " $\mathrm{B}$ " share the management of both channels. This situation is identical to what is found in distribution centers, cargo aggregators and transportation companies, according to accounts of interviewees from the e-com- merce and logistics areas. The first transformation to take place, as identified by the company, was the delivery of small shipments, which spiked in amount and number of destinations. As a result, the company looked for transportation companies that were more fractional-load oriented (small shipments) and specialized in e-business. Another change perceived by company "B" was that e-business customers are more demanding in regard to delivery punctuality.

Table 1 presents a synthesis of the main results found during the study conducted on companies "A" and "B", classified according to the analysis categories identified by the content assessment. The table below was obtained from the analysis of the speech of all respondents, identifying in these discourses possible categories (or labels) that best translate into the language of business that has been said by the respondent managers. Therefore, the answers about the process of adoption of e-business by companies can be summarized by the following groups or categories of findings: needs that led to e-business implementation; difficulties in adopting e-business; benefits brought about by the adoption of e-business; transformations in logistics; transformations in organizational structure; process of knowledge transference from the headquarters to its subsidiaries regarding the implementation of e-business; commitment to innovation; and alignment with the strategic objective.

\subsection{Analysis of Results}

For the analysis of the results, in addition to the primary data obtained, we use a comprehensive literature review to support the findings of this research to compare what was found with what is established in the literature cited, thus, we can ensure that the analysis made is based in a theoretical framework that make sour conclusions be more robust.

For Rothwell (1994) [30], Ahmed (1998) [31], Valladares, Serio \& Vasconcellos (2012) [32] and Zilber (2009) [33], there must be a strategic objective that "guides" innovation within a company. This objective is not clear for company " $\mathrm{A}$ ", and there is also no alignment between strategy and e-business because the executives never give an indication that e-business is supported by a strategy defined by the headquarters. In company "B", a foreign multinational and subsidiary of its headquarters, the adoption of e-business was done in alignment with the overall strategy; in 2004, this multinational sought to standardize management models across all areas of its subsidiaries, so that they would have identical processes, and therefore, headquarters would have better control of the branches. According to Tidd, Bessant \& Pavitt (2008) [16], developing new processes constitutes one of the ways companies innovate. This was observed 
Case of E-Business in Brazilian and Foreign Capital Companies

Table 1. Synthesis of categories found in the study.

\begin{tabular}{|c|c|c|}
\hline Category of findings & Company “A” & Company “B” \\
\hline \multirow{5}{*}{$\begin{array}{l}\text { Needs that led to } \\
\text { e-business implementation }\end{array}$} & Increase in revenue. & Alignment with global strategy, focused on innovation. \\
\hline & Channel seen by the consumer as innovative. & Increase in revenue. \\
\hline & Attractiveness and ease of purchase. & \\
\hline & Easy way to obtain information about products. & $\begin{array}{l}\text { Focus in innovation; e-business as "showcase" of the } \\
\text { company's innovative facet. }\end{array}$ \\
\hline & Variety of products gathered in a single place. & \\
\hline \multirow{4}{*}{$\begin{array}{l}\text { Difficulties in adopting } \\
\text { e-business }\end{array}$} & Lack of knowledge to develop the new sales channel. & Non-commercial project. \\
\hline & Low technological level. & Resistance from departments involved, e.g., logistics. \\
\hline & Lack of an innovation culture. & Risk of post-implementation failure. \\
\hline & Inadequate organizational structure. & \\
\hline \multirow{2}{*}{$\begin{array}{l}\text { Benefits brought by the } \\
\text { adoption of e-business }\end{array}$} & Reduced cost to process an order. & Refined criteria for hiring third parties to deliver products. \\
\hline & $\begin{array}{l}\text { Greater assortment of products made } \\
\text { available to the consumer. }\end{array}$ & resorting to a physical structure. \\
\hline \multirow{6}{*}{ Changes in logistics } & \multicolumn{2}{|c|}{ Cargo profile: small shipments. } \\
\hline & \multicolumn{2}{|c|}{ Fractioned deliveries. } \\
\hline & \multicolumn{2}{|c|}{ Assertive delivery dates. } \\
\hline & Employment of third party to operate logistics. & Same internal team for traditional business and e-business. \\
\hline & & Autonomy to ship orders (e.g.: prioritizing e-business orders). \\
\hline & Lower logistics cost. & $\begin{array}{l}\text { Hiring of transportation companies with } \\
\text { differentiated, specialized profile. }\end{array}$ \\
\hline \multirow{2}{*}{$\begin{array}{l}\text { Changes in } \\
\text { organizational structure }\end{array}$} & $\begin{array}{l}\text { Shared structure for e-business in administrative } \\
\text { aspects because the operational structure is } \\
\text { dedicated to hiring third-parties. }\end{array}$ & $\begin{array}{l}\text { Dedicated structure for e-business in } \\
\text { administrative aspects because the } \\
\text { operational structure is shared. }\end{array}$ \\
\hline & $\begin{array}{l}\text { Lack of hierarchical importance for e-business } \\
\text { because the company allocated it to the retail } \\
\text { board without strategic grounds. }\end{array}$ & $\begin{array}{l}\text { Stable structure; the area was not shifted } \\
\text { to another board because e-business } \\
\text { was given hierarchical importance. }\end{array}$ \\
\hline \multirow[t]{2}{*}{$\begin{array}{l}\text { Process of knowledge transference } \\
\text { from the headquarters to its } \\
\text { subsidiaries, regarding } \\
\text { implementation of e-business }\end{array}$} & $\begin{array}{l}\text { The headquarters could not help its subsidiaries } \\
\text { very much because it lacked knowledge of } \\
\text { e-business. At most it provided its opinion on some } \\
\text { issues, e.g. layout of products in the website. }\end{array}$ & $\begin{array}{l}\text { The headquarters, by means of Project Coordination, } \\
\text { provided the subsidiary with all information } \\
\text { necessary to implement e-business based in } \\
\text { previous knowledge and experiences. }\end{array}$ \\
\hline & No innovation management. & The company’s mission is to innovate. \\
\hline \multirow[t]{4}{*}{ Commitment to innovation } & $\begin{array}{l}\text { It is not part of the company's mission to } \\
\text { promote and maintain innovation. }\end{array}$ & Innovation is present at all levels of the company. \\
\hline & Little commitment from the board. & There are well-defined processes for managing innovation. \\
\hline & Disorganized processes. & Dedicated staff area for implementing innovations. \\
\hline & Indeterminate objectives in adopting e-business. & $\begin{array}{l}\text { Global alignment with the operations in other countries where } \\
\text { the company already operates e-business. }\end{array}$ \\
\hline \multirow{4}{*}{$\begin{array}{l}\text { Alignment with strategic } \\
\text { objectives }\end{array}$} & Low priority for the project. & Met the expectations of clients to be constantly innovating. \\
\hline & $\begin{array}{l}\text { Project initiated in departments and } \\
\text { not by a board directive. }\end{array}$ & Fulfilled the objective of strategic \\
\hline & Strategic planning without impact. & alignment proposed by the headquarters. \\
\hline & Adaptation of organizational structure. & Standardization of headquarters and subsidiaries. \\
\hline \multirow{3}{*}{$\begin{array}{l}\text { Main results obtained by using } \\
\text { e-business }\end{array}$} & & Hiring of more efficient service providers. \\
\hline & $\begin{array}{l}\text { Deliveries with better level of service } \\
\text { (punctuality and quality of product). }\end{array}$ & Success in implementing the company's strategies. \\
\hline & & Commercial expansion. \\
\hline
\end{tabular}


in this study, where both companies developed a change process to take advantage of a perceived business opportunity, in this case, e-business, allowing for increased sales in their markets, independent of the needs that drove them to innovation.

Company "A" did not show a capacity for innovation, as evidenced by the lack of trained professionals that could elaborate and implement a new project outlined by the company as an objective. Ahmed (1998) [31] asserts that, for a company to innovate, the qualifications of its executives are fundamental because they enable the fulfillment of the plans. The hiring of third parties by company "A" (logistics operator) capable of serving the e-business to meet delivery dates and provide warehousing corroborates the findings of Kalakota \& Robinson (2004) [9], who emphasize the need to hire third parties to plan and execute projects when a company cannot do everything perfectly and/or there is a lack of technical preparation by the executives, with the intention of increasing efficiency and reducing costs.

In company " $\mathrm{B}$ ", the culture of innovation is evident because it has an organizational structure oriented toward innovation that encourage sinter actions with other areas, which contributed to the success of the project. The Brazilian subsidiary received knowledge transferred from the headquarters, which had already implemented the same e-business project in other countries; therefore, the adoption of e-business occurred in a planned and organized fashion, involving a department called Project Coordination, which received and processed all information and brought the right people into the project. The whole innovation process of company " $\mathrm{B}$ " was guided by the knowledge and experience of the headquarters and was transferred to the Brazilian subsidiary, in accordance with what Oliveira Júnior (2007) [21] states about the importance of knowledge transfer between headquarters and subsidiaries. Regarding the autonomy granted by the headquarters to its subsidiaries for innovation, company "A" did not differ from company "B", a multinational of foreign capital. This corroborates the findings of Oliveira, Boehe \& Borini (2009) [19], who report that there is no difference between the autonomy given by multinational companies of either national or foreign capital and that autonomy is linked to both the time that the subsidiary is in operation and some strategic functions. Regarding the organizational structure of company " $\mathrm{B}$ ", transformations took place to better serve e-business because, according to Vasconcellos \& Hemsley (2003) [22], the speed and changes in the environment in which companies operate force them to develop adequate structures for this electronic sales channel. Amabile et al. (1996) [34] suggest that the organizational structure does not impede management allocation but makes it more difficult to inno- vate and, later, improve. Because of this, company "A" takes longer to adapt and, in the future, may be hindered in making improvements. The development process of e-business in company " $B$ " was supported from the start by the subsidiary's board as well as by the headquarters, where the issue was first discussed. Zilber (2009) [33], states that the involvement of high-level administration is fundamental to success, bringing strategic weight to the dedication to the project. However, in company " $\mathrm{A}$ ", the origin of e-business was not the board of directors, but the managerial level of the sales and marketing areas, giving the project an image of low priority throughout the company, or what Roth well (1994) [30], denotes as lack of strategic backing, and demonstrates that company "A" lacked attitudes that assured its commitment to innovation. This is in contrast to company "B", where a specific department was responsible for the e-business implementation project and managed it from the beginning (Project Coordination). Once the project had been implemented, e-business management was elevated to the managerial level. With regard to autonomy, the headquarters of company " $\mathrm{B}$ " gave total freedom to its subsidiary to modify its organizational structure. However, this freedom was limited, and headquarters' approval was needed. Oliveira, Boehe \& Borini (2009) [19], state that the autonomy given to subsidiaries is connected to strategic issues, and therefore, the headquarters of company "B", despite approving its subsidiary's whole project, also approved every step of the project because it was an important global strategy for the corporation. Regarding approval from the headquarters, a similar process occurred in company " $\mathrm{A}$ " because the headquarters granted its subsidiaries autonomy in operational issues but not in the conception of innovation.

In the present study, logistics was the key point for the success of e-business for both companies. Bornia, Donadel \& Lorandi (2006) [24], highlight the importance of logistics as a value-aggregating activity in supporting e-business, allowing a company to survive. Clearly, companies that adopted this sales channel needed to modify their logistics processes to better serve e-business. The logistics of company "B" went through transformations due to the unique characteristics of e-business, starting with the issue of shipments and deliveries that decreased in size, increased in number and were delivered to the houses of end consumers. This transformation was foreseen by Alves et al. (2005) [26], Fleury \& Monteiro (2004) [35], and Bayles \& Bathias (2000) [36], who state that traditional logistics systems are oriented towards large volumes and centralized deliveries. Conversely, company "A" did not adapt, opting to hire a logistics operator that had the necessary skills to coordinateits e-business. Johnson (2010) [17] calls this inability to 
adapt the lack of organizational availability, which consists of a learning deficiency and culminates in a barrier to the adoption of innovation.

\section{Closing Remarks}

Our findings corroborate those of Vernon \& Wells (1991) [37], Rothweel (1994) [30], Zilber (2009) [33], Valladares, Serio \& Vasconcelos (2012) [32] on the importance of the existence of alignment between the strategy and the objective of adopting an innovation, in this case of e-business. The importance of an organizational structure, that is adequate to implement e-business, is also apparent. Such a structure guarantees a level of authority for making decisions that can meet the intended objectives, as postulated by Vernon \& Wells (1991) [37], Venkatraman \& Henderson (1998) [38] and Vasconcellos \& Hemsley (2003) [22].

The main contribution of this paper is to show which structure and logistics were used for the adoption of e-business by an industry, since most of work on e-business comes to retail sector and not to industries. Regarding the first goal of this study, i.e., the identification of changes in industries in the adoption of e-business with a focus on the organizational and logistics structure, based on all the interviews summarized in the previous session, company "A" opted for the subcontracting of logistics, allocating e-business activities at a hierarchical level of no strategic relevance, while company "B" had a structure dedicated to the administrative aspect of e-business and had a Projects area dedicated to its implementation in Brazil following the headquarters' directives. Regarding changes in logistics, both companies obtained a freight profile with smaller shipments, fractioned deliveries and accurate delivery dates. Both companies mentioned the increased revenue as a motivation to adopt e-business. Company "A" also identified attractiveness and ease of purchase, ease of obtaining information on products and the variety of products gathered in a single place as motivations for adopting e-business, while company "B" mentioned alignment with the global strategy of innovation, using e-business as "showcase" of the company's innovative side as great motivators. The main difficulties in the adoption of e-business were mostly due to the lack of training for adopting this innovation (low technological capacity, lack of innovation culture and inadequate organizational structure) for company "A", while company " $B$ " mentioned the initial resistance of the departments involved (e.g., Logistics).

There were also differences between the two companies regarding the process of adopting e-business. The foreign multinationals benefited from the headquarters' previous knowledge of adopting this innovation, while the national company had a less direct adoption process, having first failed to adopt e-business. Different methods of adopting e-business are identified in companies " $\mathrm{A}$ " and " $\mathrm{B}$ " because the culture of company " $\mathrm{B}$ " is focused on innovation-also referred to in its mission-and its consumers expect the company to act innovatively, as reported multiple times in the interviews given by its employees. Thus, the adoption of e-business by company "B" occurred in a more planned and structured way because this company possessed the necessary structure and knowledge to implement a new business model in Brazil (i.e., the use of e-business). Moreover, everyone involved in new projects in company " $\mathrm{B}$ " is coached by a permanent staff detailed in the organizational structure (Project Coordination), which after training the areas involved in this innovation, returns to its original position and starts working on the development of a new process with the relevant departments.

The innovation of this paper is to compare an emerging country multinational company (MNC) and a developed country multinational company (MNC) regarding the deployment of e-business, showing how the developed country MNC has advantage over the emerging country MNC in using all his knowledge from his mother, while the emerging country MNC struggles to find the most efficient way to deploy e-business.

One limitation of the present study is the chosen method because the results cannot be generalized to all companies. In future studies, the number of interviewed companies can be increased, and studies of specific industry segments can also be performed.

\section{REFERENCES}

[1] E. Turban, et al., "Electronic Commerce: A Managerial Perspective," 4th Edition, Prentice Hall, New Jersey, 2006.

[2] T. K. Mehta and V. Shah, "e-Commerce: The Next Global Frontier for Small Business Research,” Journal of Applied Business Research, Vol. 17, No. 1, 2001.

[3] IBOPE, Instituto Brasileiro de Opinião Pública e Estatística, São Paulo. Seção IBOPE Nielsin Online Apresenta o Número de Brasileiros com Acesso à Internet Chega a 79.9 Milhões, 2012. www.ibope.com.br

[4] e-commerce.org, 2011. www.e-commerce.org.br/artigos/mercado_internet.php

[5] Internet World Statistics, "Latin America Internet Usage Statistics,” 2011.

http://www.internetworldstats.com/

[6] P. B. Tigre and J. Dedrick, "Mitos e Realidades Sobre a Difusão do e-Business nas Empresas Brasileiras,” Revista Brasileira de Inovação, Vol. 2, No. 2, 2003.

[7] R. J. Sternberg, J. E. Pretz and J. C. Kaufman, “Types of Innovation,” In: L. V. Shavinina, The International Handbook on Innovation, Elsevier Science, Oxford, 2003. http://dx.doi.org/10.1016/B978-008044198-6/50011-5 
[8] M. Porter, "Strategy and the Internet," Havard Business Review, Boston, 2001.

[9] R. Kalakota and M. Robinson, "E-Business: Estratégias para Alcançar o Sucesso no Mundo Digital,” 2nd Edition, Bookman, Porto Alegre, 2004.

[10] A. K. F. Barlow, N. Q. Siddiqui and M. Mannion, "Developments in Information and Communication Technologies for Retail Marketing Channels,” International Journal of Retail \& Distribution Management, Vol. 32, No. 3, 2004, pp. 157-163. http://dx.doi.org/10.1108/09590550410524948

[11] A. G. P. Fuchs and P. F. Fleury, "Evolução das Práticas Logísticas do B2C Brasileiro: Um Estudo de Caso,” In: Encontro Anpad, Atibaia, 2003.

[12] E. Stal and M. A. Campanario, "Empresas Multinacionais de Países Emergentes-O Crescimento das Multilatinas,” Revista Inteligência, São Paulo, Vol. 1, No. 3, 2011.

[13] S. Mishra, "Web Aggregation in India: e-Business Models in New Economy," Journal Business and Emerging Markets, Vol. 2, No. 3, 2010, pp. 252-266.

[14] E. M. Rogers, "Diffusion of Innovations," 4th Edition, The Free Press, New York, 1995.

[15] OCDE, “Manual de Oslo 2005-Organização para Cooperação e Desenvolvimento Econômico,” 2005. http://www.pucrs.br/raiar/prime/download/manual de os lo-3ed.pdf

[16] J. Tidd, J. Bessant and K. Pavitt, “Gestão da Inovação,” 3rd Edition, Bookman, São Paulo, 2008.

[17] M. Johnson, "Barriers to Innovation Adoption: A Study of e-Markets. Technology Management Research Group,” The Open University, Milton Keynes, 2010.

[18] J. Dunning, "Multinational Enterprises and the Global Economy,” Addison-Wesley, Workhingan, 1993.

[19] M. M. Oliveira Jr., M. Boehe and F. M. Borini, "Estratégia e Inovação em Corporações Multinacionais: A Transformação das Subsidiárias Brasileiras," Saraiva, São Paulo, 2009.

[20] T. Khanna and K. Palepu, "Emerging Giants: Building World-Class Companies in Developing Countries," Harvard Business Review, October 2006.

[21] M. M. Oliveira Jr., "Transferência de Conhecimento e o Papel das Subsidiárias em Corporações Multinacionais Brasileiras,” In: M. T. L. Fleury and A. Flerury, Internacionalização e os Países Emergentes, Altas, São Paulo, 2007.

[22] E. Vasconcellos and J. Hemsley, "Estrutura das Organizações,” Editora Pioneira, São Paulo, 2003.

[23] R. M. Costa, P. L. Melo, M. V. Cardoso and C. E. C. Ferreira, "Ambiente Interno para Inovação em uma Empresa de e-Commerce: O Caso Net Flores,” XIII Semead-Seminário em Administração, FEA-USP, São
Paulo, 2010.

[24] A. C. Bornia, C. M. Donadel and J. A. Lorandi, "A Logística do Comércio Eletrônico,” ENEGEP, Brasil, 2006.

[25] L. C. Coelho and R. L. Cristo, "A Gestão da Cadeia de Suprimentos Utilizando Conceitos de Logística Virtual," In: Seget-Simpósio De Excelência Em Gestão E Tecnologia, SEGET, Resende, 2007.

[26] C. S. Alves, et al., “A Importância da Logística para o e-Commerce: O Exemplo da Amazon.com,” 2005. http://www.congressousp.fipecafi.org/artigos12004/an_re sumo.asp?cod_trabalho=375

[27] M. M. F. Vieira and D. M. Zouain, "Pesquisa Qualitativa em Administração,” FGV, Rio de Janeiro, 2004.

[28] R. K. Yin, "Estudo de Caso: Planejamento e Métodos,” 3rd Edition, Bookman, São Paulo, 2003.

[29] A. S. Godoy, "Estudo de caso Qualitativo,” In: C. K. Godoi, R. Bandeira-de-Mello and A. B. Silva, "Pesquisa Qualitativa em Estudos Organizacionais: Paradigmas, Estratégias e Métodos,” Saraiva, São Paulo, 2006.

[30] R. Rothwell, "Towards the Fifth-Generation Innovation Process," International Marketing Review, Vol. 11, No. 1, 1994, pp. 7-31. http://dx.doi.org/10.1108/02651339410057491

[31] P. K. Ahmed, "Benchmarking Innovation Best Practice," An International Journal, Benchmarking, 1998.

[32] P. S. D. A. Valladares, L. C. D. Serio and Vasconcellos, "Capacidade de Inovação: Revisão Sistemática da Literatura,” XXXVI Anpad Rio de Janeiro, 2012.

[33] S. N. Zilber, "Strategic Use of the Internet and e-Business: the 'Celta' Case at GM Brazil," International Journal of Information Technology and Management, Vol. 8, No. 1, 2009, pp. 85-106. http://dx.doi.org/10.1504/IJITM.2009.022272

[34] T. M. Amabile, R. Conti, H. Coon, J. Lazenby and M. Herron, "Assessing the Work Environment for Creativity," The Academy of Management Journal, Vol. 39, No. 5, 1996, pp. 1154-1184. http://dx.doi.org/10.2307/256995

[35] P. F. Fleury, “O Desafio Logístico do e-Commerce,” 2004.

http://www.ilos.com.br/web/index.php?option=com_cont ent\&view=article\&id=1006\%3Aartigos-o-desafio-logistic o-do-e-commerce\&catid=4\&Itemid=182\&lang=br

[36] D. L. Bayles and H. Bhatia, "E-Commerce Logistics \& Fulfillment: Delivering the Goods,” Prentice Hall, Upper Saddle River, 2000.

[37] R. Vernon and L. T. Wells Jr., "The Manager in the International Economy,” Prentice Hall, New York, 1991.

[38] M. Venkatraman and J. C. Henderson, "Real Strategies for Virtual Organizing,” MIT Sloan Management Review, Vol. 40, No. 1, 1998. 